\title{
REPRESENTACIÓN ICONOGRÁFICA DE LAS MUJERES EN LA PUBLICIDAD DE PERFUMES
}

\author{
ICONOGRAPHIC REPRESENTATION OF WOMEN \\ IN PERFUME ADVERTISING
}

\author{
Ana M. MUÑoZ-MUÑ̃Z \\ Universidad de Granada \\ anamaria@ugr.es
}

\author{
M. Mar MARTÍNEZ-OÑA \\ Universidad Europea de Madrid \\ mariadelmar.martinez@universidadeuropea.es
}

\begin{abstract}
Resumen: Se analizan las iconografías femeninas representadas en la publicidad de perfumes a partir de una muestra de cincuenta anuncios gráficos publicados desde el año 2000 hasta el 2015. La metodología aplicada fue la iconográfica, a partir de la cual se crearon categorías: diosas del Olimpo, princesas, mitos cinematográficos, mujer y serpiente y mujer y felino. Los resultados muestran que la pervivencia de estas mitologías en la publicidad gráfica instaura en el subconsciente colectivo unos estereotipos femeninos y cánones de belleza sexualizados que reafirman la pervivencia idealizada de conocidos mitos en la publicidad gráfica de este sector.
\end{abstract}

Palabras clave: Mujeres. Iconografía. Publicidad. Belleza. Perfumes. 


\begin{abstract}
The female iconographies represented in perfume advertising are analyzed from a sample of fifty graphic advertisements published from 2000 to 2015. The applied methodology was iconographic, from which categories were created: Olympian goddesses, princesses, cinematographic myths, woman and snake and woman and feline. The results show that the survival of these mythologies in graphic advertising establishes feminine stereotypes and sexualized beauty canons in the collective subconscious that reaffirm the idealized survival of well-known myths in graphic advertising in this sector.
\end{abstract}

Key Words: Woman. Iconography. Advertising. Beauty. Perfumes.

\title{
1. INTRODUCCIÓN
}

Las mujeres a lo largo de la Historia han sido representadas e identificadas desde una perspectiva androcéntrica, clasificadas como buenas y malas, diosas y diablesas... éstas últimas, también fueron relacionadas con el estereotipo de la mujer devoradora de hombres la Femme Fatale (Bornay, 1990). Este estereotipo femenino aún vigente jugó un papel destacado en su difusión y distribución sobre todo en la industria cinematográfica.

En general, se puede identificar una dicotomía iconográfica que establece dos ámbitos opuestos en el que se agrupan dos actitudes y dos mundos en paralelo, el privado y el público, aunque existen excepciones como pueden ser las diosas paganas, donde se excluye al personaje mitológico de Atenea:

[...] un análisis detallado de la figura de Atenea muestra que la diosa no era considerada como una mujer desde un punto de vista androcéntrico, ya que no aparece investida de las cualidades 
femeninas por excelencia; no es esposa ni madre. Frente a una Atenea virgen y representada con atributos masculinos como el yelmo y la lanza, a modo de una "virgo bellatrix", [...] Atenea es la mujer que refrenda los valores patriarcales adoptando el rostro femenino de la masculinidad. (Beteta, 2009: 170).

La diversidad iconográfica se mantiene en la cultura visual contemporánea, las mujeres son las protagonistas de escenificar en la publicidad una dicotomía iconográfica entre el Bien y el Mal, que se ha relacionado a lo largo de la historia con lo privado y lo público. Esta personificación de lo bueno y lo malo se identifica con la recreación de roles femeninos consolidados a través de la publicidad, en concreto en este artículo se centra en la publicidad gráfica de perfumes por su gran contenido erótico-sexual, donde las mujeres desempeñan un rol principal como protagonistas absolutas del anuncio.

El estudio de la iconografía femenina desde una perspectiva de género ha sido desarrollado por diversos autores (Diego, 1987, 1992; Bornay, 1990, 1994, 1996, 1998, 2009; Castañer, 1993; Ulierte, 1997, 1998; Sauret, 2007; García Torralbo, 2009; Aumente, 2010; etc.). La identificación de los medios como espacios de lucha entre representaciones o concepciones de la realidad fue analizado por Berger y Kellner (1985), sin olvidar el clásico GenderAdvertisements de Goffman (1979) acerca de la hiperritualización de la feminidad en la publicidad.

En cuanto a los estereotipos en publicidad destacan los trabajos de León (2001); Garrido Lora (2007); etc. Entre los estudios relacionados con imágenes publicitarias que analizan un anuncio concreto destaca el de Fernández, Baños y García (2014), y desde la perspectiva semiótica y de género sobre la interconexión entre iconografía y publicidad el de López Díez (2003). Otra investigación de análisis iconográficos, en este caso de un anuncio en concreto es el de Arocena y Zubiaur (2012) centrado en la empresa Dolce \& Gabbana. Sobre las diversas iconografías catalogadas en este artículo hay que señalar la bibliografía sobre la relación entre las 
diosas clásicas en el cine y la televisión de Lapeña Marchena (2006).

El interés de esta investigación sobre la iconografía en el sector comercial de perfumes se debe a que este tipo de publicidad fomenta la pervivencia de estereotipos, a lo que se suma el carácter erótico y sexual que adquieren las mujeres que pasan a ser objetos-sujetos y sujetos-objetos, lo que da lugar a una similitud entre conceptos aparentemente opuestos, que sin embargo se unifican y mimetizan ante el espectador y que incluso en diversos casos presenta a la mujer cosificada que pasa desapercibida ante la mirada adiestrada del consumidor/espectador. Por ello, este artículo tiene como objeto analizar e identificar las diversas iconografías femeninas representadas en los anuncios gráficos de perfumes en la publicidad desarrollada en el denominado mundo occidental donde en teoría existe mayor igualdad entre hombres y mujeres. No obstante, los estereotipos creados con base iconográfica, en los cuales se representa la identidad femenina no se equiparan con la igualdad de género.

Se analizan diversos ejemplos publicitarios, en los que se mantienen antiguas iconografías femeninas, readaptadas e incluso a veces presentadas ante el espectador como innovadoras, aun siendo una reinterpretación de antiguos mitos. Arocena y Zubiaur (2012) consideran que en el imaginario simbólico construido y extendido por las representaciones audiovisuales de los medios de comunicación de masas es en sí mismo una forma tácita de violencia (no siempre) sobre el género femenino. Es necesario, extrapolar esta idea al sector del perfume, para detectar sí dichas representaciones gráficas pueden ser identificadas como violentas para/con las mujeres, ya que éstas quedan situadas bajo un rol impuesto y aceptado/normalizado socialmente. Las iconografías femeninas examinadas simbolizan eróticamente y sexualmente a las mujeres asociadas a un producto, al igual que el perfume publicitado:

El publicista entonces acude a la palabra y a la imagen para despertar el deseo y cautivar, pretende decir lo que deseamos escuchar y se dedica a mostrar lo que esperamos ver; la 
publicidad nos narra historias y representa el mundo (Zapata, 2012: 4).

Y sin duda, es aquí donde radica el engaño visual, la representación de féminas como diosas y diablesas erotizadas, crea una falsa identidad de la imagen que las mujeres deben de tener de sí mismas, por ello hay que plantearse si ¿Las mujeres desean parecerse a los personajes femeninos de los anuncios? o ¿Son los anuncios quienes proyectan en las mujeres la imagen de cómo deben ser las mujeres? ¿Las imágenes que vemos son representaciones o concepciones de la realidad? ¿Existe manipulación en la imagen que se ofrece de las mujeres en los anuncios de perfumes?

[...] las estrategias estéticas en la publicidad buscan en gran parte efectos de credibilidad, autoridad, simpatía, confianza y poder (Zapata, 2012: 4).

Y efectivamente, todas son mujeres poderosas, diosas inalcanzables, a las cuales, las mujeres consumidoras del producto ¿pretende aspirar?, aunque se debe de tener muy presente que:

[...] las imágenes que se difunden de las mujeres a través de la publicidad suelen ser estereotipadas e inexactas y negativas, describiendo a las mujeres más por su apariencia que por sus capacidades (Bernad, 2010: 191).

El analfabetismo visual anula la capacidad crítica al asimilar de forma inconsciente las imágenes, quedando la sociedad vulnerable ante la publicidad que presenta/representa un mundo paralelo irreal en el cual el espectador (voayeur) busca estímulos visuales, aquí es donde la manipulación a través de imágenes ejerce un gran poder al ser protagonizadas por perfectas mujeres seductoras e idealizadas, diosas y diablesas estéticamente inigualables. 


\section{MATERIAL Y MÉTODO}

El desarrollo de este trabajo propició la obtención de una muestra de cincuenta anuncios gráficos del sector de perfumes, todos ellos protagonizados por y para mujeres, publicados desde el año 2000 hasta el 2015. La localización de las imágenes se realizó en Internet con diversos buscadores (Google Chrome, Internet Explorer, Firefox, etc.) y criterios de búsqueda avanzada (anuncios de perfumes, mujer y perfumes, etc.), en algunas ocasiones se utilizaron repositorios de publicidad (adsoftheworld. com, adeevee.com). Tras un primer análisis iconográfico de los cincuenta anuncios gráficos, 26 se clasificaron dentro de la iconografía femenina de diosas del Olimpo, 4 en la de princesas, 8 en la de mitos cinematográficos, 4 de mujer y serpiente, 8 de mujer y felino; estos tres últimos grupos quedaban asociados con la iconografía de diablesa (Lilith) y por extensión con la Femme Fatale, cuya iconografía también es identificada con Lilith (Martínez-Oña y Muñoz-Muñoz, 2015; Bornay, 1990). Paralelamente, se comprobó y verificó el año del anuncio, con el fin de que todas las imágenes pertenecieran al periodo objeto de estudio.

La elección de las muestras del sector de perfumes permitió trabajar con imágenes que contenían una alta carga erótica y que convertían a la mujer-protagonista del anuncio en un producto más que complementa al elemento anunciado, e incluso en diversas ocasiones aparece mimetizada con el frasco de perfume (cosificación), una referencia mujer-objeto. Algunos autores lo identifican como mujer que exhibe un símbolo fálico, convirtiéndose el frasco de perfume en dicho símbolo (Campos, 2008); es entonces cuando cabe preguntarse de quién es el elemento fálico: de la mujer representada en el frasco de perfume, o del frasco de perfume dónde se representa la mujer. La cosificación de la mujer en los anuncios de perfumes se convierte en una constante al ser mimetizada con el producto anunciado, en este caso el frasco de perfume. 
La metodología elegida para analizar las representaciones gráficas fue la iconográfica, “[...] la iconografía podría definirse como la disciplina cuyo objeto de estudio es la descripción de las imágenes, o como han señalado algunos autores, la escritura en imágenes" (Rodríguez López, 2005: 2). La iconografía es la lectura de las imágenes junto con el estudio de la evolución de los iconos, su análisis, transformación a lo largo de los siglos y sus pervivencias.

Una vez compilada la muestra, se elaboró una segunda clasificación basada en estudios iconográficos (Aghion, Lissarrague y Barbillon, 1997), que identifican y clasifican las diferentes iconografías tanto judeocristianas como paganas en relación con sus diferentes atributos iconográficos y ejemplifica cada una con diversas representaciones artísticas tras una búsqueda de referencias iconográficas en la Historia de Arte, con la finalidad de encontrar antecedentes iconográficos de los anuncios de perfumes. Lo cual, posibilitó identificar los anuncios y catalogar diferentes categorías iconográficas: Diosas del Olimpo, Princesas, Mitos cinematográficos, Mujer y serpiente y Mujer y felino.

Las Diosas del Olimpo incluye representaciones femeninas con semejanzas a diosas clásicas paganas como los anuncios de J'adore de Dior protagonizado por Charlize Theron (2009, 2010, 2011), donde Afrodita (Venus), diosa de la belleza del amor y del deseo, fue la iconografía identificada con la protagonista. Las Princesas mantienen el estereotipo femenino de los cuentos de hadas, con los cuales se ha relacionado y se relaciona a las niñas de todas las épocas, por ejemplo el perfume Nina, de Nina Ricci protagonizado por Frida Gustavsson (2013) y que guarda similitudes iconográficas con el personaje de Blancanieves, al igual que ella, la protagonista porta el atributo iconográfico de la manzana, elemento gráfico que posee una importante lectura iconográfica relacionada con las mujeres en diferentes culturas occidentales (clásica, cristiana, etc.). En Mitos cinematográficos, quedan clasificados los anuncios que tienen una estrecha relación con mitos femeninos nacidos del cine como Marilyn Monroe, por ejemplo, el perfume Christina Aguilera (2010), y también 
publicidad con referencias iconográficas al personaje cinematográfico de Gilda, como en la gráfica publicitaria del perfume Dita Von Teese (2008). La iconografía del Mal a lo largo de la historia ha sido protagonizada por el personaje de la diablesa Lilith y por extensión de Femme Fatale. Diversas iconografías englobadas aquí como Mujer y serpiente y Mujer y felino, muestran esta identificación con Lilith, como por ejemplo el anuncio de Hypnotic Poison de Dior protagonizado por la actriz Mónica Bellucci (2008) quién era fotografiada junto a una serpiente.

La creación de fichas para catalogar las imágenes facilitó la definición de las características estéticas de cada una de las iconografías representadas por las protagonistas de los anuncios.

\section{ICONOGRAFÍA FEMENINA EN LA PUBLICIDAD DE PERFUMES}

La sociedad occidental se encuentra inmersa en una cultura visual donde las imágenes desempeñan un poderoso y silencioso rol, por ello es necesario replantearse la necesidad de realizar una lectura iconográfica de las imágenes que permita releer el significado de éstas para evitar el engaño y posible manipulación del consumidor (de la sociedad) por la publicidad, y la anulación de estereotipos femeninos arraigados en la psique colectiva.

Las iconografías femeninas se han clasificado a lo largo de la historia en dos grandes grupos: iconografía del Bien (relacionada con la vida privada y el ámbito doméstico) e iconografía del Mal (relacionada con vida pública y el ámbito público). Dentro del primer grupo en este artículo se ha incluido la categoría de Diosas del Olimpo, junto a la de Princesas, aunque las diosas paganas se pueden considerar una excepción al no entrar dentro de la clasificación más extendida por las religiones. Ya que estas diosas mantienen una relación no tan estricta con la vida privada, sí que mantienen determinados roles de género relacionado con esta línea iconográfica que se contrapone a la línea iconográfica del Mal, que estaría 
constituida por la Femme Fatale, Mujer y serpiente, y Mujer y felino, tres iconografías asociadas al personaje de la diablesa Lilith (Martínez-Oña y Muñoz-Muñoz, 2015).

Tras un análisis detallado de las imágenes se identificó con la representación de diosas un $52 \%$ de las gráficas publicitarias, un $8 \%$ con iconografías de princesas, frente a un $40 \%$ de iconografías relacionadas con la diablesa Lilith (Femme Fatale -que englobaba mitos cinematográficos, mujer y felino, mujer y serpiente-) (Gráfico1); estableciéndose así, un paralelismo entre diosas y diablesas, con un mayor porcentaje de las representaciones iconográficas de diosas, un $60 \%$ frente a un $40 \%$ de iconografías identificadas con Lilith.

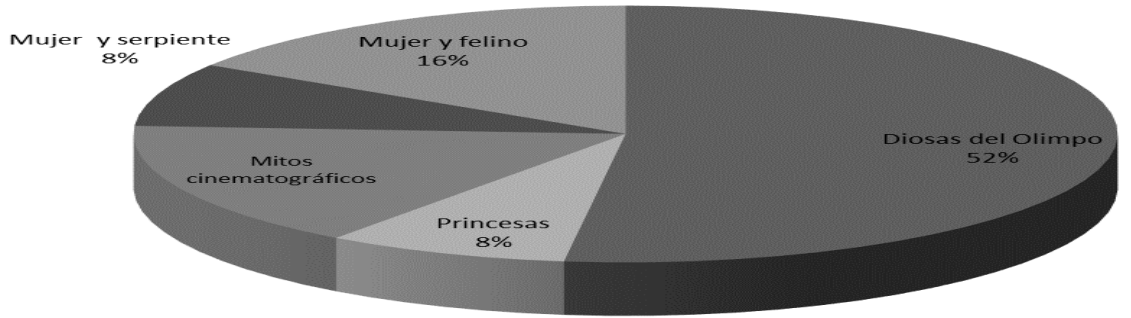

Gráfico 1. Representación de distintas iconografías femeninas en los anuncios de perfumes. Elaboración propia.

El mayor porcentaje está representado por Diosas del Olimpo (generalmente asociadas con Venus, la diosa de la Belleza), donde se presenta a una mujer perfecta, imagen socialmente idealizada que posee características estéticas relacionadas con la belleza: joven, delgada y bella. A esto hay que añadir el poder que se le atribuye relacionado con el adquisitivo, rodeadas de oro y lujos; Mujeres/Diosas estéticamente inigualables, ubicadas en una escenografía inmejorable con vestimentas y escenarios similares, acusadas de poder y riqueza, resaltado por el excesivo color dorado incluso en sus cabellos, color que en ocasiones es sustituido por el blanco, el cual conlleva connotaciones con las diosas de la antigua 
Grecia Clásica, y en algunos casos por la similitud en los ropajes con el péplum griego como se observa en el anuncio del perfume Organza de Givenchy (Figura 5).

La admiración por el cabello rubio, el deseo de poseerlo de este color, la creencia de que coadyuda a acentuar la hermosura de un rostro femenino, ha primado ampliamente sobre el gusto por el pelo negro. El prestigio tradicional de aquél no lo tiene éste. Ello viene ya atestiguado en varios textos de la Antigüedad. Homero pintó con dorada cabellera a Venus, Juno y Minerva; Ovidio también ensalzó este color, e incluso Marcial [...] (Bornay, 1994: 91).

Un ejemplo de la imagen de la mujer que se proyecta en la publicidad de perfumes que representa a una diosa con grandes atributos erótico-sexuales, es la del anuncio de J'adore de Dior (Figura 1), la semejanza iconográfica relaciona a la actriz, modelo y protagonista del anuncio Charlize Theron con la diosa Afrodita (Venus), la diosa del amor y la belleza, más concretamente con el episodio iconográfico del Nacimiento de Venus, donde la diosa surge (nace) de las aguas. Esta iconografía analizada fue publicada en el año 2007 y posteriormente también se pudo observar en la portada de la revista Vogue (Figura 2), entre otras, esto confirma la pervivencia de este episodio mitológico en la publicidad y editorial gráfica, no solamente en el sector comercial de perfumes, sino en otros sectores comerciales que también lo reinterpretan. 

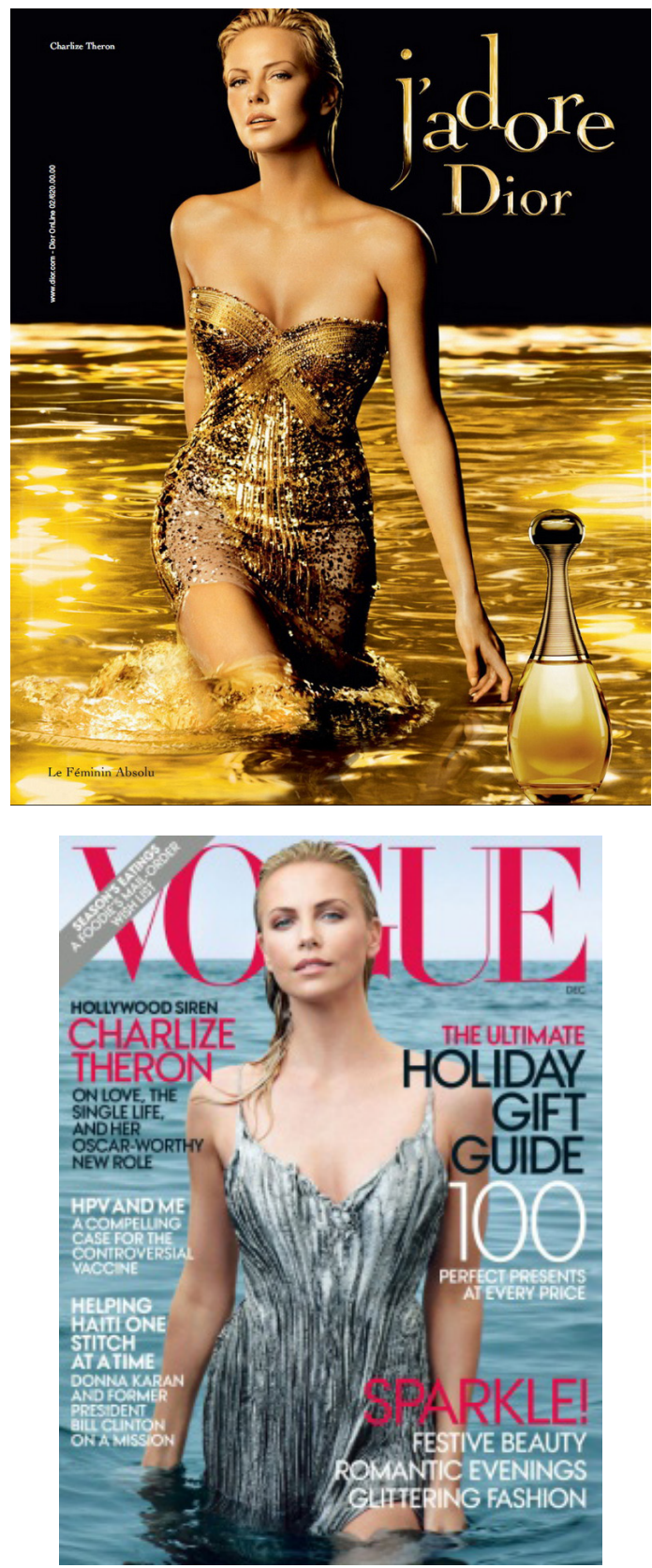

Figura 1 y 2. Anuncio J'adore de Dior, 2007; portada de la revista Vogue en diciembre de 2011, http://www.dior.com y https://www.vogue.com [25/06/2018]. 
En estas imágenes con connotaciones eróticas la sensualidad se concentra en el rostro y en la figura de la protagonista que queda cubierta con sugerente ropa mojada, la actriz y modelo Charlize Theron en ambas imágenes enlaza con este episodio iconográfico en el que la diosa del amor y la belleza nace de las aguas, concretamente de la espuma del mar. Una de las primera representaciones artísticas sobre este tema se encuentra en el relieve de mármol el trono de Ludovisi (Figura 3) realizado entre los siglos VI y V a C. que narra el nacimiento de la diosa saliendo de las aguas, a la cual cubren con ropajes su sexo, dos figuras femeninas identificadas como Horas. Más concreto es el episodio iconográfico del nacimiento de Venus, en el cual la diosa nace del mar después de que se lanzarán al agua los genitales del dios Urano, tal y como narraba Hesíodo "el relato de Hesíodo vincula la diosa a la mar, de donde la hace nacer: toda una serie de representaciones ilustran este nacimiento- son las Venus anadyyomenai, una de las cuales adorna el trono de Ludovisi" (Aghion, Lissarrague y Barbillon, 1997: 352). Este episodio iconográfico ya lo encontramos representado desde la Antigüedad Clásica. Kenneth Clark (1993) en su estudio sobre Afrodita indica como antes de Praxísteles las figuras de la diosa no aparecen desnudas, sino con el cuerpo cubierto por un ropaje ligero y adherido, draperie mouillée o paños mojados. Esta conocida iconografía identificada con la mitología clásica conlleva una gran carga erótica femenina, donde se representa a mujeres sexuales dentro del prototipo de belleza actual, y aunque no aparecen desnudas, sus ropas muy ceñidas dejan intuir el cuerpo femenino y en diversas ocasiones aparecen mojadas, detalle que remarca más el erotismo de la figura femenina. 

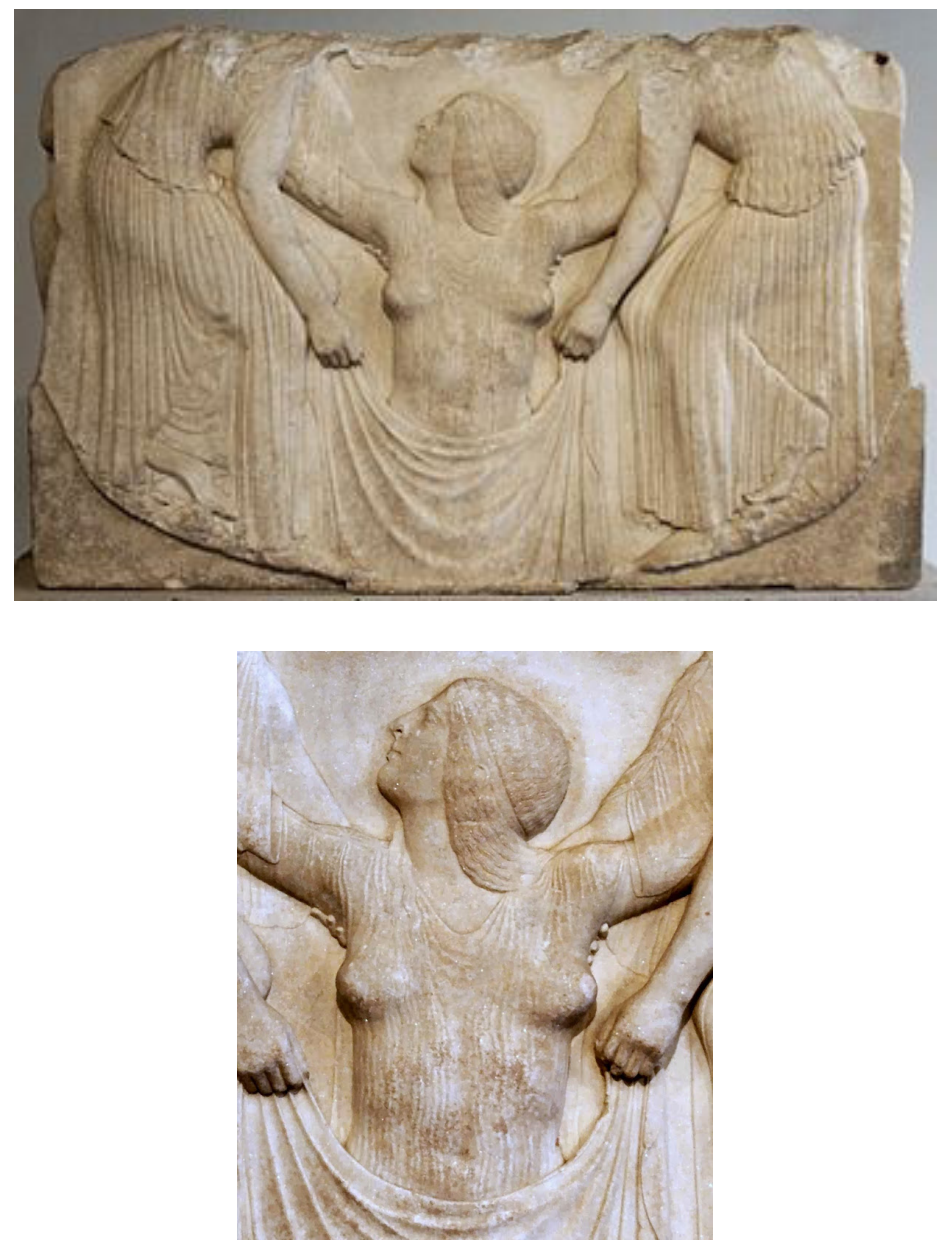

Figura 3. El trono de Ludovisi, https://arte.laguia2000.com/escultura/tronoludovisi [25/06/2018].

La diosa Afrodita/Venus posee un destacado papel en la publicidad del sector comercial de perfumes. Aunque también es innegable el protagonismo de Venus en la Historia del Arte, sobre todo para justificar el desnudo femenino; en la época actual es en la publicidad donde desarrolla 
un papel fundamental; sin embargo, en el cine y la televisión este papel no ha sido tan amplio (Lapeña, 2006). Siendo en la pintura y escultura principalmente donde la Diosa de la Belleza se convierte en una temática atractiva recurrente para los artistas.

La identificación de las mujeres con el amor y la belleza hace que su valoración parta de estos dos conceptos, alejados del raciocinio y del intelecto, convirtiéndose así la mujer en un producto más, un objeto de deseo. Es una forma de cosificar a mujeres:

Una forma de denigrar a las personas es "cosificándolas" es decir tratando a las personas como cosas que se pueden usar, independientemente de lo que piensen o sientan. La mujer como objeto decorativo, es un elemento más que forma parte del producto anunciado [...] (García Pérez, 2009: 13).

Esta cosificación se proyecta en las siguientes imágenes que representan a diosas objeto/sujeto en los anuncios de Intense de Jean Paul Gaultier y de Organza de Givenchy; en ambos existe una similitud entre el cuerpo femenino y el frasco de perfume (Figuras 4 y 5). La mujer pasa a ser un objeto publicitado más, que se relaciona con un frasco de perfume, un elemento, un objeto que se puede coger y usar. Concretamente en la publicidad de Givenchy (Figura 5), la similitud es tal que incluso la protagonista mantiene el mismo tamaño que el frasco de perfume, ofreciendo la posibilidad al espectador de elegir entre ambos. Y aunque ambos anuncios representan a diosas, su poder se encuentra en ser elemento u objeto de deseo, nada más. 

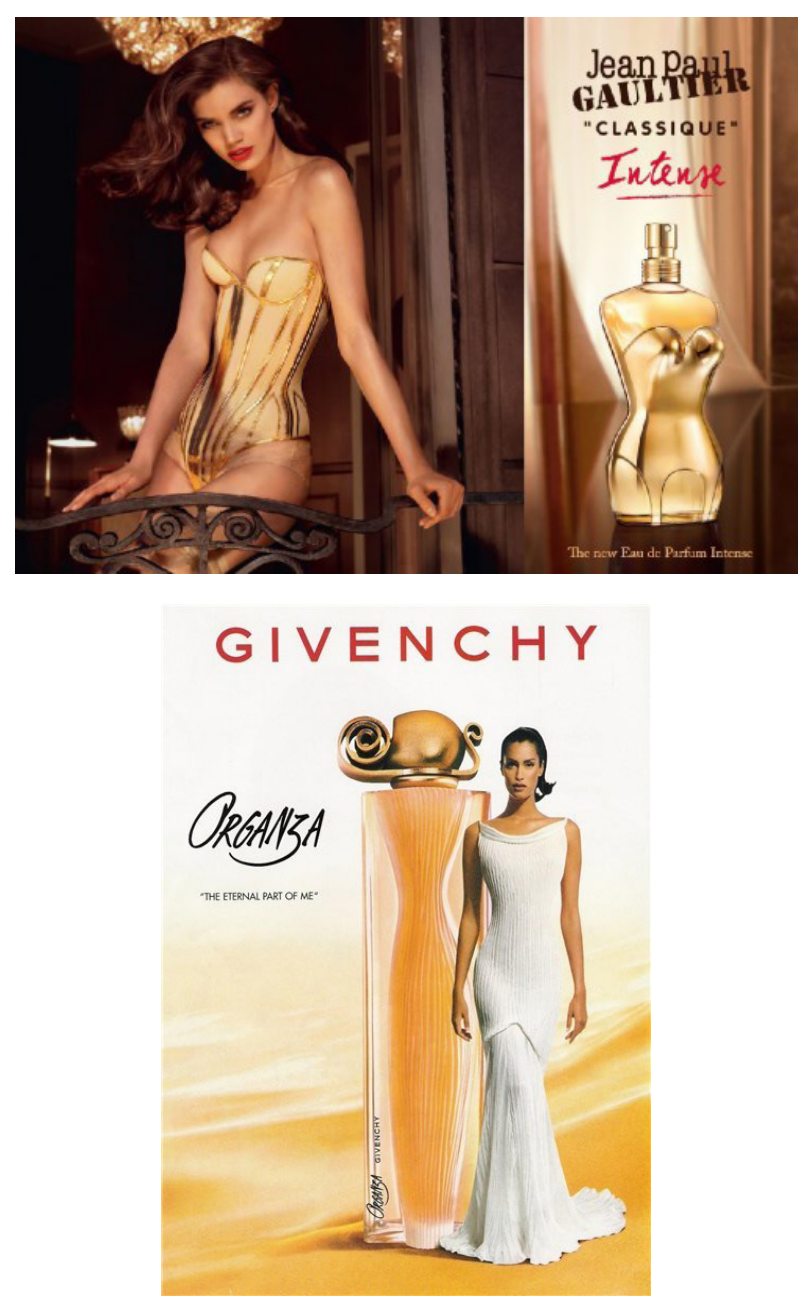

Figuras 4 y 5. Anuncio Intense de Jean Paul Gaultier y anuncio Organza de Givenchy, http://www.stylistic.fr/2014/09/classique-intense-jean-paulgaultier_48553 y https://belleza.trendencias.com/perfumes/givenchy-organza un-perfume-sensual-elegante-y-exotico-que-nos-ha-enamorado [25/06/2018].

En la sociedad visual es importante identificar entre ámbitos y objetos. Alfonso López Quintás (2010) defiende la importancia de educar, y para ello utiliza el concepto de ámbito en contraposición con el de 
objeto. Este último término identifica aquello que desde una sociedad profundamente consumista el individuo se cree con el poder de desear y poseer, inclusive a las personas. Desde un punto de vista más profundo, el autor identifica el término ámbitos para establecer un valor y un respeto hacia los objetos y cómo no a las personas. Sin duda, son normas educacionales que se enfrentan a una cultura visual, donde la publicidad ejerce un ejemplo contrario a dicha teoría, al utilizar la imagen de la mujer como un mero objeto. Sin embargo, no hay que olvidar las motivaciones comerciales y el negocio en una sociedad consumista. "La publicidad es una fábrica de sueños donde las imágenes femeninas se convierten en objetos de placer y de deseo; objetos bellos que se convierten en escaparates de diferente tipología de productos" (Piñeiro y Costa, 2003: 3). La ensoñación que produce la publicidad representando la imagen de diosas inalcanzables hace perdurar la creación de un mundo idílico deseado socialmente basado en silenciosas y manipuladas imágenes, donde las mujeres son las protagonistas absolutas.

En contraposición con el grupo iconográfico anterior identificado con el Bien, la muestra gráfica obtenida representa en paralelo una imagen diferente de las mujeres en él que se agrupan diversas iconografías relacionadas con la Femme Fatale (Lilith): mitos cinematográficos, mujer y felino, mujer y serpiente. Este grupo iconográfico relacionado con la iconografía del Mal representa un 40\% de la muestra, y remite a la primera Femme Fatale de la historia creada en el seno de la cultura androcéntrica, Lilith, (Martínez-Oña y Muñoz-Muñoz, 2015) mujer, diablesa, que también se identifica como la negra (Bornay, 1990):

En algunas representaciones, Lilith aparece como una figura femenina alada, de larga cabellera. En otras su cuerpo desnudo termina en forma de cola de serpiente. En el Zohar y en diversas fuentes se la denomina Lilith la ramera, la perversa, la falsa e, incluso, la negra (Bornay, 1990: 26). 
No obstante, el término Femme Fatale se desarrolla a finales del siglo XIX en Europa, donde se sucedieron una serie de acontecimientos históricos-culturales que estuvieron marcados por una misoginia que quedó plasmada en multitud de manifestaciones artísticas. Es principalmente en el cartelismo desarrollado en este siglo donde podemos ver un precedente de la imagen misógina de la mujer en la publicidad gráfica identificada como una Femme Fatale, aunque hubo que esperar al cine para que se perpetuará este estereotipo.

Diversos animales fueron asociados con Lilith (también identificada con la diosa babilónica Ishtar) a lo largo de la historia, entre ellos como elementos iconográficos destacan la serpiente y los felinos, entre otros. La conjunción mujer-serpiente dentro de la cultura cristiana, se ha relacionado con el pecado, la lujuria, etc. cualidades de la diablesa. Las principales características de Lilith y por extensión la Femme Fatale han sido su mirada perversa, su belleza, su maldad, y cómo elemento iconográfico puede estar o no acompañada de la serpiente, o por un felino. La Femme Fatale no suele aparecer con la serpiente, pero si ataviada de diversos elementos fetichistas relacionados con la atracción sexual (guantes largos, ligas, etc.).

Las figuras 6 y 7 muestran la evolución iconográfica del mito de Lilith en publicidad, donde los elementos relacionados con los animales, concretamente con serpiente y felino quedan plasmados en la indumentarias de las protagonistas: en un pantalón de piel de serpiente que se mimetiza con las extremidades inferiores de la mujer mientras atrapa a su presa (en este caso a un hombre), y en un vestido de estampación felina con un prominente escote, dejándose entrever en ambos casos los senos femeninos. Junto a esto, hay que destacar la importancia simbólica de la cabellera femenina, tema estudiado por Erika Bornay (1994). Ambas protagonistas poseen una abundante y poderosa melena atribuyendo connotaciones eróticas-sexuales que siguen presentes en la publicidad de principios del siglo XXI:

[...], la melena femenina como constante de mito, como agente 
fetichista, incitador de secretas imágenes en la imaginación del varón, ha motivado secularmente infinidad de narraciones orales, escritas y plásticas. Elemento de enorme capacidad perturbadora en los mitos eróticos de la sociedad masculina, la cabellera opulenta de la mujer simboliza primordialmente la fuerza vital, primigenia [...], y la tracción sexual (Bornay, 1994: 15).
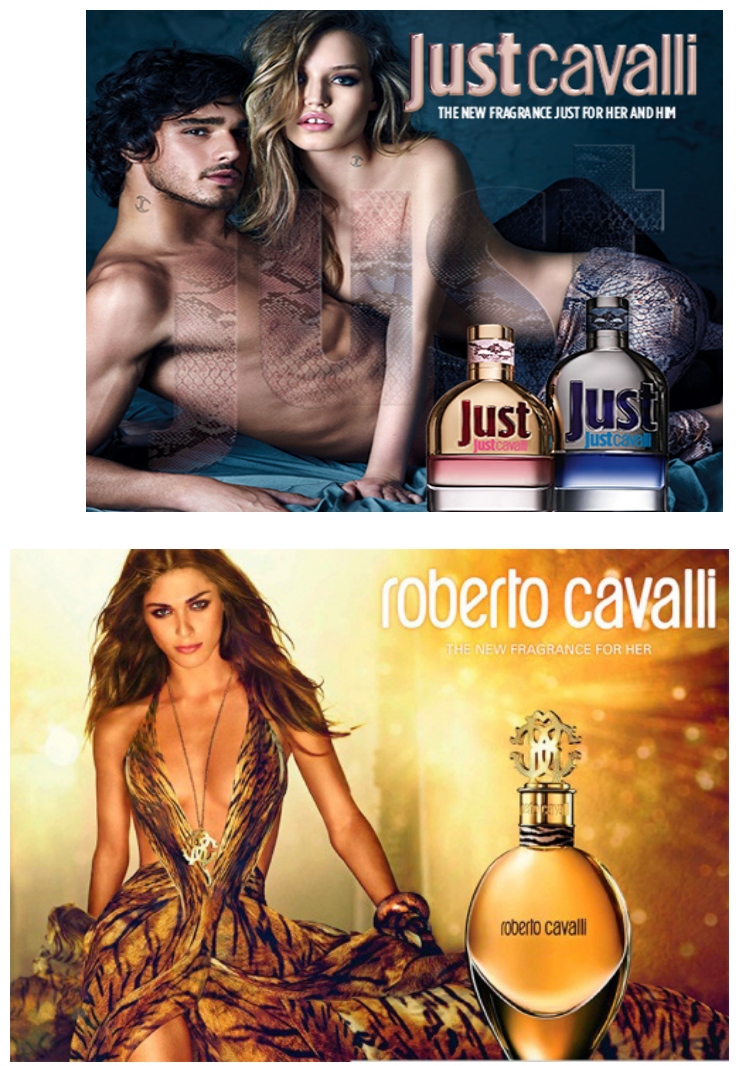

Figuras 6 y 7. Anuncio de la fragancia JustCavalli y anuncio del perfume Roberto Cavalli, http://indiatoday.intoday.in/story/mickjaggers-daughters-saucy-perfume-ad-outrages-muslim-group-hollywoodcelebrities/1/369367.html y https://www.trendencias.com/modelos/elisasednaoui-la-modelo-de-la-primavera-de-el-corte-ingles [25/06/2017]. 
Ambas mujeres se mimetizan con el animal que portan en sus vestiduras. La mujer serpiente se sitúa sobre el hombre mientras un elemento fálico, el bote de perfume masculino, está situado sobre su sexo. De esta manera se matiza el carácter erótico-sexual del anuncio, donde vemos a una devoradora de hombres, el poder es ejercido por la mujer dominadora de la situación. Por el contrario, la mujer-felino avanza desafiante ante el espectador mientras un gran escote y un colgante forman una punta de flecha que señala su sexo, en ambos anuncios la mujer desempeña un papel erótico sexual íntimamente asociado con el sector comercial de perfumes.

La evolución del mito judío de Lilith desemboca en el estereotipo de mujer devoradora de hombres, una iconografía femenina estandarizada gracias a personajes femeninos cinematográficos como Gilda, donde guantes negros y peinado se reinterpretan en la iconografía femenina de perfumes como se analiza en el anuncio Erotique y Femme Totale de Dita Von Teese (Figuras 8 y 9).
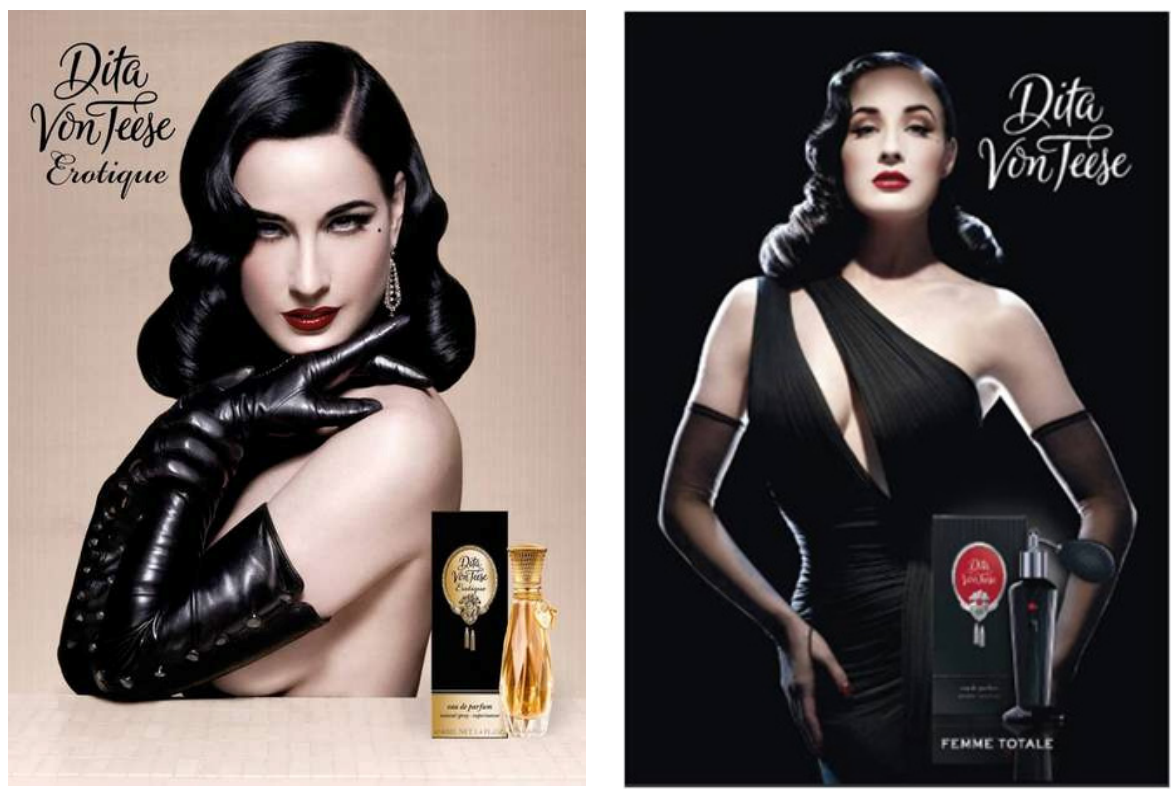

Figuras 8 y 9. Anuncio Erotique de Dita Von Teese y anuncio del perfume Femme Totale de Dita Von Teese, https://www.fragrantica.es/perfume/Dita-VonTeese/Erotique-19801.html y https://www.fragrantica.com/news/Dita-VonTeesepresents-her-first-perfume-2587.html [26/06/2018] 
Cómo rasgos psicológicos hay que matizar que la Femme Fatale se caracteriza por su poder, su capacidad de dominio del hombre, incitación al mal, frialdad, gran sexualidad, lujuria. Mujer perversa que se asocia al pecado de la sexualidad, de la carne. "Parlar de la dona fatal és fer referència directa a un personatge femeni captivador d'homes i dones, eròtic i seductor, que utilitza el seu actratiu natural com a eïna de subsistència i superació personal" (Hidalgo-Marí, 2013: 51).

El receptor de la publicidad vive en un mundo donde las imágenes se han convertido en el principal medio de comunicación, se visualizan tantas imágenes, que no se plantea la necesidad de releerlas "Para el receptor, los estímulos recibidos a través de los ojos suelen aparecer como representación exacta de la realidad" (Fernández, Baños y García, 2014). Esto genera un problema ya que la manipulación que ejercen las imágenes constituye una falsa realidad donde las mujeres son representadas bajo una antigua mirada androcéntrica, que mantiene vigentes diversos estereotipos. "El mensaje publicitario ofrece un retrato parcial de una sociedad ideal, un reflejo sesgado, deformado y, en muchas ocasiones, inverosímil, pero que va calando en el imaginario colectivo" (Feliu y Fernández, 2010: 2).

Este imaginario colectivo fomenta una imagen de la mujer estéticamente perfecta, rodeada de poder y objeto de deseo. Envuelta así, en un misógino disfraz que representa arcaicas iconografías femeninas. La falsa imagen femenina ofrecida en la publicidad de perfumes no favorece la igualdad de género, a la vez que fomenta cautiverios femeninos (Villareal, 2010) donde la mujer se presenta representando iconografias que generan falsos estereotipos hacia la mujer del siglo XXI.

El ser humano vive inmerso en una sociedad visual, donde la mayoría de las mujeres no se cuestionan la imagen que se ofrece de ellas, por el contrario, tienden a intentar reproducir estas imágenes estereotipadas, quizás porque:

La enorme influencia de los modelos socioculturales es 
especialmente visible en las narraciones mitológicas que, oportunamente reescritas de acuerdo a los distintos tiempos históricos, y articuladas en el cine, el arte y la literatura, han contribuido a modelar y difundir las ideas y prácticas sociales patriarcales que continúan profundamente arraigadas $y$ normalizadas en el subconsciente social. Bajo esta lógica, sería imposible concebir la historia de las mujeres sin una historia de sus representaciones, de sus mitos y de la decodificación de sus imágenes, pues son aspectos que expresan la construcción y evolución del imaginario social femenino y de toda la estructura social que lo acepta, conforma y reproduce (Beteta, 2009: 165).

\section{CONCLUSIONES}

La publicidad de perfumes fomenta la estandarización de determinadas iconografías femeninas, antiguas mitologías nacidas en la cultura androcéntrica que protagonizan la publicidad gráfica de dicho sector. De este modo mantienen vivas iconografías que instauran unos estereotipos y cánones de belleza sexualizados y manipulados, que confirman la pervivencia idealizada de conocidos mitos en la publicidad gráfica del sector comercial de perfumes.

Estas iconografías representan a diosas paganas, princesas, Lilith - mujer y serpiente, mujer y felino, mitos cinematográficos-, personajes que ejercen un gran poder visual ante la sociedad. Las diosas paganas que son las más numerosas en anuncios destinados al público femenino representan un $60 \%$, lo que justifica la existencia/pervivencia de los idealizados mitos que identifican a las mujeres con las diosas.

La mujer ideal aparece simbolizada en antiguas iconografías femeninas, como son las representaciones de diosas y diablesas, dos polos opuestos que se muestran tremendamente erotizados. Éstas reproducen lo que se denomina cautiverios femeninos que ubican a las mujeres 
ejemplarizadas como iconográficas de perfectas diosas inalcanzables, objetos de deseo, frente a las de perfectas mujeres lujuriosas devoradoras de hombres, identificadas con el estereotipo de la Femme Fatale.

Las imágenes de las mujeres se han mimetizado con el concepto de belleza y sexualidad, se han convertido en objeto/sujeto de deseo, alejadas de cualidades como el intelecto. En esta publicidad mantiene la cosificación de la mujer al presentarla como un objeto más de consumo identificado en su cuerpo. La mujer sujeto/objeto se convierte en el elemento primordial del anuncio publicitario que en algunos casos es mimetizada con el propio frasco de perfume, característica observada en la línea iconográfica del Bien, mientras que en la línea iconográfica del Mal, el bote de perfume se convierte en un elemento fálico con respecto a la imagen femenina.

La iconografía creada desde una perspectiva androcéntrica ha impuesto una imagen falsa que se ofrece a las mujeres como modelo a imitar. La pervivencia de estas mitologías instaura en la publicidad gráfica unos estereotipos femeninos junto a una cosificación femenina que resulta ser una forma de violencia de género hacia las mujeres. Por ello, es necesario replantearse desvincular a las mujeres del posicionamiento iconográfico y objetual que desarrollan en la publicidad gráfica del sector comercial de perfumes.

La imagen irreal es convertida en una imagen normalizada a través de la mirada del espectador/voyeur que asimila dicha estética en los anuncios de perfumes. Sin embargo, la iconografía representada se encuentra muy alejada de la vida de las mujeres reales y de la realidad social en la que vivimos. 


\section{REFERENCIAS BIBLIOGRÁFICAS}

AGHION, I.; LISSARRAGUE, F. y BARBILLON, C. (1997). Guía iconográfica de los héroes y dioses de la antigüedad. Madrid: Alianza.

AROCENA, C. y ZUBIAUR, N. (2012). "En el limbo de lo invisible". Revista Fotocinema 4, 10-36.

AUMENTE RIVAS, M. P. (2010). "La imagen de las mujeres a través de su propia mirada". Creatividad y Sociedad: Revista de la Asociación para la Creatividad 15, 3-28.

BERGER, P.L. y KELLNER, H. (1985). La reinterpretación de la sociología. Madrid: Espasa Calpe.

BERNAD MONFERRER, E. (2010). "Ilicitud de las representaciones degradantes y humillantes del cuerpo femenino en la publicidad. Especial referencia a la anorexia”. Icono 14 8.3, 186-207.

BETETA MARTÍN, Y. (2009). "Las heroínas regresan a Ítaca. La construcción de las identidades femeninas a través de la subversión de los mitos". Investigaciones feministas 0, 163-182.

BORNAY, E. (1990). Las hijas de Lilith. Madrid: Cátedra.

(1994). La cabellera femenina. Un diálogo entre poesía y pintura. Madrid: Cátedra.

(1996). "Eva y Lilith: Dos mitos femeninos de la religión judeocristiana y su representación en el arte". En Historia del arte y mujeres, M. T. Sauret Guerrero (coord.), 109-122. Málaga: Universidad de Málaga.

(1998). Mujeres de la Biblia en la pintura del Barroco: Imágenes de la ambigüedad. Madrid: Cátedra.

(2009). Arte se escribe con M de mujer. Barcelona: Sd-edicions.

CAMPOS RODRÍGUEZ, V. B. (2008). "El fetiche: un resplandor que ciega en la magna mujer de la publicidad". Pensar la publicidad 2.2, 171-188.

CASTAÑER LÓPEZ, X. (1993). La imagen de la mujer en la plástica vasca 
contemporánea (s. XVIII-XX): aproximación a una metodología de género. Bilbao: Universidad País Vasco.

CLARK, K. (1993). El desnudo. Madrid: Alianza Editorial.

DIEGO, E. (1987). La mujer y la pintura del XIX español: (cuatrocientas olvidadas y algunas más). Madrid: Cátedra.

(1992). El andrógino sexuado. Eternos ideales, nuevas estrategias de género. Madrid: Visor.

FELIU ALBALADEJO, Á. y FERNÁNDEZ POYATOS, M. D. (2010). "La mujer en la publicidad: hacia nuevos discursos". En La representació de gènere a la publicitat del segle XXI: Girona, 25 i 26 de maig de 2009, s. p. Girona: Universitat de Girona. En http:// rua.ua.es/dspace/handle/10045/15822 [09/09/2013].

FERNÁNDEZ FERNÁNDEZ, P.; BAÑOS GONZÁLEZ, M. y GARCÍA GARCÍA, F. (2014). "Análisis iconográfico de la publicidad audiovisual de perfumes. El caso J'Adore". Icono 14 12, 398-430.

GARCÍA PÉREZ, N. (2009). La mujer en la publicidad. TFM. Salamanca: Universidad de Salamanca, http://gredos.usal.es/jspui/ handle/10366/80263 [14/06/2018].

GARCÍA TORRALBO, M. C. (2009). "Heroínas, Reinas y Perversas: La seducción y el poder en el Antiguo Testamento". En I Congreso Virtual sobre historia de las mujeres, s. p. Jaén: Archivo Histórico Diocesano de Jaén. En https://dialnet.unirioja.es/servlet/ articulo? codigo $=4098358[15 / 12 / 2013]$.

GARRIDO LORA, M. (2007). "Estereotipos de género en la publicidad". Creatividad y sociedad 11, 53-71.

GOFFMAN, E. (1979). Gender Advertisements. New York: Harper and Row Publishers.

HIDALGO-MARÍ, T. (2013). De Pandora i altres mals: la divulgació industrial-cultural del mite de la dona fatal. Tesis Doctoral. Alicante: Universidad de Alicante, http://rua.ua.es/dspace/ handle/10045/29107 [10/06/2014].

LAPEÑA MARCHENA, O. (2006). "El ideal de la belleza y la nostalgia 
del pasado: Venus en el cine y la televisión”. Iberia: Revista de la Antigüedad 9, 167-190.

LEÓN, J. L. (2001). Mitoanálisis de la publicidad. Barcelona: Ariel.

LÓPEZ DÍEZ, P. (2003). "Las mujeres en el discurso iconográfico de la publicidad”. En Formación y acreditación en Consultoría para la igualdad de mujeres y hombres, 415-470. Vitoria: Emakunde (también en http://www.pilarlopezdiez.eu/pdf/ MujeresDiscurIcoPublicidad.pdf [09/09/2013]).

LÓPEZ QUINTÁS, A. (2010). La experiencia estética y su poder formativo. Bilbao: Deusto.

MARTÍNEZ-OÑA, M. M. y MUÑOZ-MUÑOZ, A. M. (2015). “Análisis iconográfico del mito de Lilith en la publicidad”. Revista Latina de Comunicación Social 70, 611-626 (también en http://www. revistalatinacs.org/070/paper/1062/RLCS-paper1062.pdf [19/12/2015]).

PIÑEIRO OTERO, M. T., y COSTA SÁNCHEZ, C. (2003). "Representaciones femeninas en la publicidad. Una propuesta de clasificación". Revista de la Seeci 10, 1-16 (también en http://www. seeci.net/revista/index.php/seeci/article/view/208 [30/08/2014]).

RODRÍGUEZ LÓPEZ, M. I. (2005). "Introducción a los estudios iconográficos y a su metodología". En E-excellence, s. p. En https://webs.ucm.es/centros/cont/descargas/documento10868.pdf [01/09/2014].

SAURET GUERRERO, T. (2007). "La estética del silencio: iconografía femenina de la época isabelina". Boletín de Arte 28, 127-151.

ULIERTE VÁZQUEZ, L. (1997). "Sirenas: del mito a la publicidad". En La mujer en el arte español. VIII Jornadas de Arte: Madrid, 26-29 de noviembre de 1996, 559-570. Madrid: Alpuerto.

(1998). "Imágenes de la mujer: de Gea a María". Cuadernos de Arte 29, 183-200.

VILLAVERDE SOLAR, M. D. (2014). "La imagen en la publicidad y el arte: con mujeres, ¿para mujeres?”. Arte y sociedad. Revista de 
investigación 6, s. p. (también en http://asri.eumed.net/6/pubhttp:// asri.eumed.net/6/publicidad-arte-mujer.htmllicidad-arte-mujer. html [01/09/2014]).

ZAPATA WHITE, M. A. (2012). "Cuerpo y territorio: Itinerario del deseo". Publicuidad. Revista latinoamericana de publicidad 4(1), s. p. (también en https://revistas.upb.edu.co/index.php/publicuidad/ article/view/1454 [14/11/2014]).

Recibido el 9 de abril de 2018.

Aceptado el 27 de junio de 2018. 